\title{
ANALYSIS OF THE INVENTORY METHODS FOR POLLUTANTS IN AMBIENT AIR IN THE EIA REPORTS (ENVIRONMENTAL IMPACT ASSESSMENT) FOR INVESTMENT PROPOSALS IMPLEMENTED ON THE TERRITORY OF RIEW RUSE FOR THE 2013-2016 PERIOD
}

\author{
$\underline{\text { Antoaneta Stefanova }}^{1}$
}

\author{
${ }^{1}$ Ruse University Angel Kanchev, 8 Studentska, Ruse, Bulgaria
}

\begin{abstract}
The inventory methods used for pollutants in the Republic of Bulgaria for the purposes of the EIA reports are: Updated uniform inventory methodology for emissions of harmful substances in the air (Order № 165/20.02.2013 of MEW), EMEP/EEA Air pollutant emission inventory guidebook of the EEA and AP-42, Compilation of Air Pollutant Emission Factors of EPA - U.S. Environmental Protection Agency. The choice of methods used for the assessment is made by the independent expert who works on it. As a result of using different inventory methods for pollutants in ambient air in similar installations (sites) the recorded values for the amounts of emitted pollutants are different. The purpose of the study is to make a comparison between the estimated amounts of the same pollutants in similar sites /performing one and the same activity/ by using different methods in the approved EIA reports and register the deviations; to assess the need of establishing a uniform methodology for assessing the Ambient air component in EIA reports, reflecting the essence of the planned investment - new investment or expansion of an existing site.
\end{abstract}

Keywords: ambient air, pollutant, environmental impact assessment, inventory

\section{Introduction}

The main objective of this study is to examine the existing inventory methods for pollutants in ambient air, emitted from sites which are subject to mandatory assessment of their impact on the environment.

Sub-objectives of the study are:

- Grouping of major installations by categories of activities according to Annex № 1 of the Law on Environmental Protection [5].

- Establishing of implemented inventory methods for pollutants in approved environmental impact assessment reports from the period considered and the corresponding category of activity;

- A study on potential deviations in the results of the inventory of pollutants emitted in ambient air for sites within the same category of activities using different methods;

- Potential consequences of applying different inventory methods for pollutants in similar sites.

To provide sufficient information for the methods applied in environmental impact assessment reports for large installations, all approved requests for reports have been studied, as well as completed EIA reports for the 2013 - 2016 period, regarding investment proposals that will be implemented on the territory covered by the Regional Inspectorate of Environment and Water Ruse.

The article discusses only that part of the reports that forms a sufficiently representative sample for drawing a conclusion. 


\section{Materials and Methods (or Experimental)}

The information necessary for completing the analysis is provided by:

- using publicly available information, accessible on the official website of the competent authority for approving Environmental Impact Assessment reports - Regional Inspectorate of Environment and Water - Ruse [7, 8, 9, 10, 11, 12, 13, 14, 15, 16, 17, 18]

- using publicly available information, accessible on the official website of Ministry of Environment and Water [6, 9, 10, 12, 13, 14, 18]

- information provided by Regional Inspectorate of Environment and Water - Ruse, under the Law on Access to Public Information - for the procedures with missing data in public registers. The basic methods used for obtaining results, subject to this analysis, are:

- $\quad$ inventory methods for pollutants, approved by the Ministry of Environment and Water of the Republic of Bulgaria [1];

CORINAIR methodology of the European Environment Agency [2];

AP-42 methodology of the U.S. Environmental Protection Agency [4];

\section{Results and Discussion}

a. Arranging big installations by activity categories according to Annex № 1 of the Law on Environmental Protection [5].

From the review of all approved projects for the 2013-2016 period that will be implemented on the territory of RIEW - Ruse, the following were established:

$\checkmark$ Sector Intensive farming of poultry or pigs - item 21. Farms for intensive breeding of poultry and pigs from Annex № 1 of the Law on Environmental Protection [5].

Facilities for intensive farming of poultry - 5 pcs $[7,9,11,16,18]$ and Facilities for intensive farming of pigs -2 pcs $[15,17]$

$\checkmark$ Sector Quarries, open cast mining and peat extraction, not included in Annex № 1 of the Law on Environmental Protection [5], but subject to mandatory EIA procedure by the decision of the competent authority - RIEW - Ruse

Implemented under Chapter Six of the Law on Environmental Protection is one site of this sector [13]

$\checkmark$ Sector Quarries, open cast mining and peat extraction, included in item 34 Opencast digging in quarries and mines of raw materials in areas above 25 hectares or peat extraction in areas above 150 hectares from Annex № 1 of the Law on Environmental Protection [5]

Implemented under Chapter Six of the Law on Environmental Protection is one site of this sector

$\checkmark$ Sector Inland waterways and ports, included in item 23.1 Inland waterways and ports serving ships on inland waterways that allow passing of ships with displacement over 1350 tons from Annex № 1 of the Law on Environmental Protection [5 ]

One procedure on environmental impact assessment has been completed. [10]

$\checkmark$ Sector Waste Treatment, included in item 24 Installations for hazardous waste disposal by incineration, chemical treatment or discharge under the Law on Waste Management in Annex № 1 of the Law on Environmental Protection [5] 
One procedure on environmental impact assessment has been completed. [12]

$\checkmark$ Sector Integrated chemical installations included in item 10 Integrated chemical installations for industrial production of chemical substances using chemical conversion processes, where separate installations are functionally related, from Annex № 1 of the Law on Environmental Protection [5]

One procedure on environmental impact assessment has been completed. [14] Chart 3.1-1 shows the shares of individual sectors, made equal to $100 \%$.

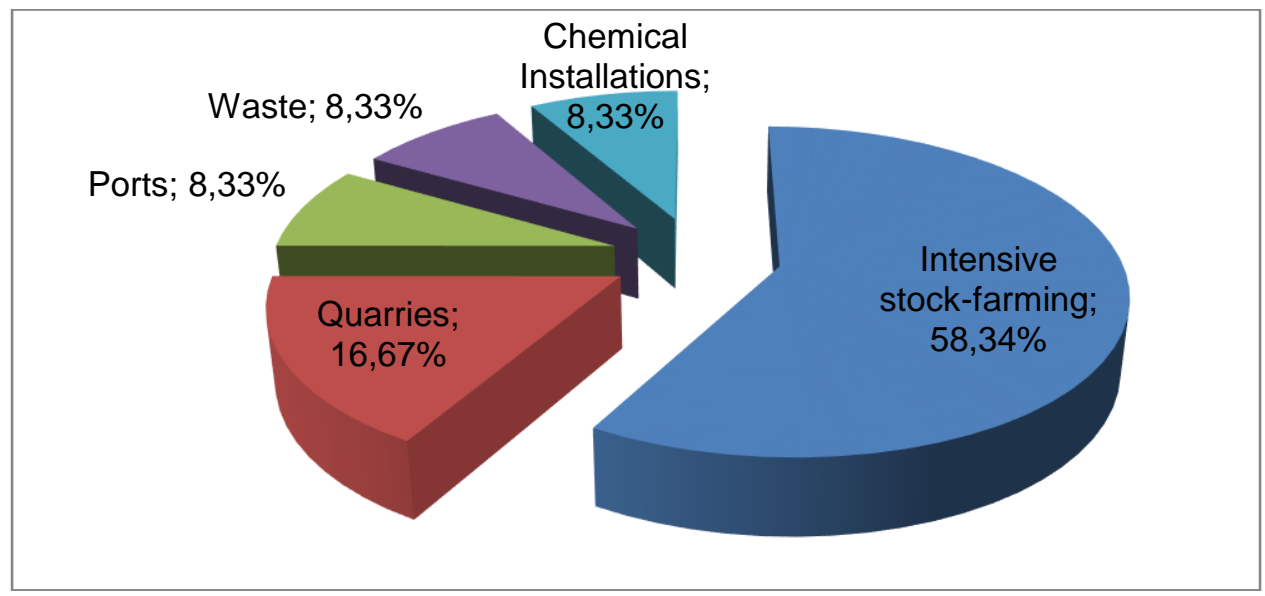

Chart 3.1-1

A large share (above 50\%) is taken by Intensive livestock farming Sector, followed by Sector Quarries with two sites for this period or $16,67 \%$ of the total share of procedures. The rest of the sectors are presented with one approved site. For this reason they are not mentioned further in the analysis.

b. Establishing of implemented inventory methods for pollutants in approved environmental impact assessment reports from the period considered from the corresponding category of activity;

$\checkmark$ Sector Intensive livestock farming

Table 3.2.-1 presents tabular data on the methods used to assess the annual emission quantities into the ambient air for the sites in this sector, grouped by principal activities. 


\section{Table 3.2.-1}

\begin{tabular}{|c|c|c|c|}
\hline Activity & Methodology MEW[1] & Methodology EPA[4] & Methodology EEA[2,3] \\
\hline $\begin{array}{l}\text { Poultry farming, stay } \\
\text { in production } \\
\text { premises }\end{array}$ & 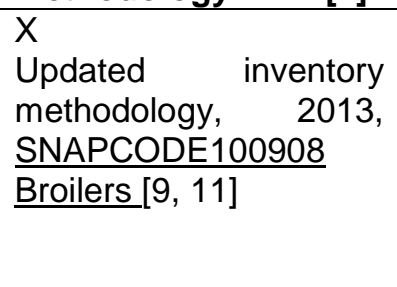 & $\begin{array}{lr} & \\
\text { Ammonia } & \text { Emissions } \\
\text { from } & \text { Animal } \\
\text { Husbandry } & \text { Operations } \\
{[16,18]} & \end{array}$ & $\begin{array}{l}\mathrm{X} \\
\text { EMEP/EEA air pollutant } \\
\text { emission inventory } \\
\text { guidebook }-2009, \quad 4 . \mathrm{B} \\
\text { Animal husbandry and } \\
\text { manure management, Tier } \\
2 \text { [7] }\end{array}$ \\
\hline $\begin{array}{l}\text { Heating of } \\
\text { manufacturing } \\
\text { buildings }\end{array}$ & $\begin{array}{lr}\text { X } & \\
\text { Updated } & \text { inventory } \\
\text { methodology, } & 2013, \\
\text { SNAPCODE } & 020205 \\
{[11,16,18]} & \\
\end{array}$ & -- & $\begin{array}{l}\mathrm{X} \\
\text { EMEP/EEA air pollutant } \\
\text { emission } \\
\text { guidebook }-2007, \text { SNAP } \\
\text { 020302/020305, Tier } 1 \text { [7] }\end{array}$ \\
\hline $\begin{array}{l}\text { Pig farming, stay in } \\
\text { production premises }\end{array}$ & -- & -- & $\begin{array}{l}\mathrm{X} \\
\text { EMEP/EEA air pollutant } \\
\text { emission inventory } \\
\text { guidebook }-2013 \text { (final } \\
\text { updated version), Part B: } \\
\text { sectoral guidance chapters, } \\
\text { T. 3B Manure } \\
\text { management[15,17] }\end{array}$ \\
\hline
\end{tabular}

Submitted data show a considerable discrepancy in the selected inventory methods for ammonia pollutant released from the bird breeding premises. In $40 \%$ of the reports regarding the intensive poultry farming activity, an Updated uniform inventory methodology is used for emissions of harmful substances in the air (Order № 165/20/02/2013 of the MEW) [1], in another 40\% - AP-42, Compilation of Air Pollutant Emission Factors of EPA - U.S. Environmental Protection Agency [4], and only $20 \%$ (one EIA report) use - EMEP / EEA Air pollutant emission inventory guidebook of the EEA, 2009 [2].

Various methods are also applied in the annual inventory of pollutants emitted from heating in production buildings. $60 \%$ of the reports use the methodology approved in Bulgaria [1], and $20 \%$ (one EIA report) - the Methodology of the European Environmental Agency [2].

The percentages in this activity do not add up to $100 \%$, because one of the sites within the sector does not emit pollutants from combustion processes directly into the ambient air.

For the "Pig farming, stay in production premises" activity, one and the same inventory method is used for pollutants expected in both approved sites.

\section{$\checkmark$ Sector Quarries}

Table 3.2.-2 presents tabular data on the methods used to assess the annual emission quantities into the ambient air for the sites in this sector, grouped by principal activities.

Table 3.2.-2

\begin{tabular}{|l|l|l|l|}
\hline Activity & Methodology MEW[1] & $\begin{array}{l}\text { Methodology } \\
\text { EPA[4] }\end{array}$ & Methodology EEA[3] \\
\hline $\begin{array}{l}\text { Use of transport equipment } \\
\text { (stage "Construction") }\end{array}$ & $\begin{array}{l}\text { X } \\
\text { Updated inventory } \\
\text { methodology, 2013 } \\
{[8,13]}\end{array}$ & -- & -- \\
\hline $\begin{array}{l}\text { Emissions from stage } \\
\text { "Operation" -- }\end{array}$ & $\begin{array}{l}\mathrm{X} \\
{[13]}\end{array}$ & $\begin{array}{l}\mathrm{X} \\
{[137]}\end{array}$ \\
\hline
\end{tabular}

Note: In the approved assignment and EIA report for " Extraction of subsurface natural resources - construction materials (limestone) from "Pravda" area in the village of Pravda, Dulovo Municipality, Silistra district", [8] no information is available about the inventory methods used for pollutants from the operational stage of the quarry. 
In two of the reviewed reports for similar sites from the Quarry sector there isn't enough information for the analysis. Therefore they are excluded.

c. A study on potential deviations in the results of the inventory of pollutants emitted in ambient air for sites within the same category of activities using different methods.

For the purposes of the study we will use data from the approved EIA reports for Sector Intensive livestock farming - poultry breeding, because the two main activities in this sector have the largest number of approved reports and it's typical to apply all three basic inventory methods for pollutants in ambient air.

With the purpose of establishing potential deviations in the results, the following procedures are being carried out:

- Inventory of ammonia pollutant from the stay of birds in the premises by all three methodologies used in the reports for each site;

- Inventory of nitrogen oxides pollutant from heating of the production premises by both methodologies submitted in the approved EIA reports.

Data is presented in tabular form for clarity and easy comparison of potential deviations. The results of the pollutant inventory for the site, specified in the EIA report by the independent experts, are indicated on gray background in the table.

Table 3.3.-1 Inventory of ammonia pollutant from vital activity of birds.

\begin{tabular}{|l|l|l|l|}
\hline $\begin{array}{l}\text { Pollutant NH3 from vital activity of } \\
\text { birds (production buildings) }\end{array}$ & $\begin{array}{l}\text { Methodology } \\
\text { MEW[1] }\end{array}$ & $\begin{array}{l}\text { Methodology } \\
\text { EPA[4] }\end{array}$ & $\begin{array}{l}\text { Methodology } \\
\text { EEA[3] }\end{array}$ \\
\cline { 2 - 4 } & \multicolumn{2}{|c|}{ NH3, t/py } \\
\hline $\begin{array}{l}\text { Farm for intensive breeding of } \\
102850 \text { broilers, town of Vetovo [7] }\end{array}$ & 48.17 & 8.011 & 22.49 \\
\hline $\begin{array}{l}\text { Farm for intensive poultry breeding, } \\
\text { village of Chervena voda [9] }\end{array}$ & $\mathbf{4 6 8 . 3 7}$ & 148.266 & 248.714 \\
\hline $\begin{array}{l}\text { Intensive broiler farming, village of } \\
\text { Shumentsi [11] }\end{array}$ & $\mathbf{1 1 5 8 . 2 5}$ & 192.646 & 540.54 \\
\hline $\begin{array}{l}\text { Poultry farm, village of Smirnenski } \\
\text { [16] }\end{array}$ & 21.748 & $\mathbf{2 . 5 7 6}$ & 10.149 \\
\hline $\begin{array}{l}\text { Poultry farm, village of Kichenitsa } \\
\text { [18] }\end{array}$ & 54.470 & $\mathbf{1 2 . 2 4 6}$ & 25.419 \\
\hline
\end{tabular}

Table 3.3.-2 Inventory of nitrogen oxides pollutant from heating of production premises

\begin{tabular}{|l|l|c|}
\hline NOx pollutant, heating of production buildings & Methodology MEW [1] & $\begin{array}{l}\text { Methodology } \\
\text { EEA [3] }\end{array}$ \\
\cline { 2 - 3 } & \multicolumn{2}{|c|}{ NOx, t/y } \\
\hline $\begin{array}{l}\text { Farm for intensive breeding of 102 850 broilers, town of } \\
\text { Vetovo }\end{array}$ & 0.315 & $\mathbf{0 . 4 7 0}$ \\
\hline Intensive broiler farming, village of Shumentsi [11] & $\mathbf{1 9 . 4}$ & 29.02 \\
\hline Poultry farm, village of Smirnenski [16] & $\mathbf{0 . 8 7 0}$ & 1.28 \\
\hline Poultry farm, village of Kichenitsa [18] & $\mathbf{2 . 3 3 7}$ & 3.48 \\
\hline
\end{tabular}

The results of the inventory of ammonia and nitrogen oxides pollutants emitted into ambient air from the two basic activities in the sector, and obtained by calculations based on the three applicable inventory methods for pollutants, are presented graphically in charts 3.3.-1 and 3.3.-2. 


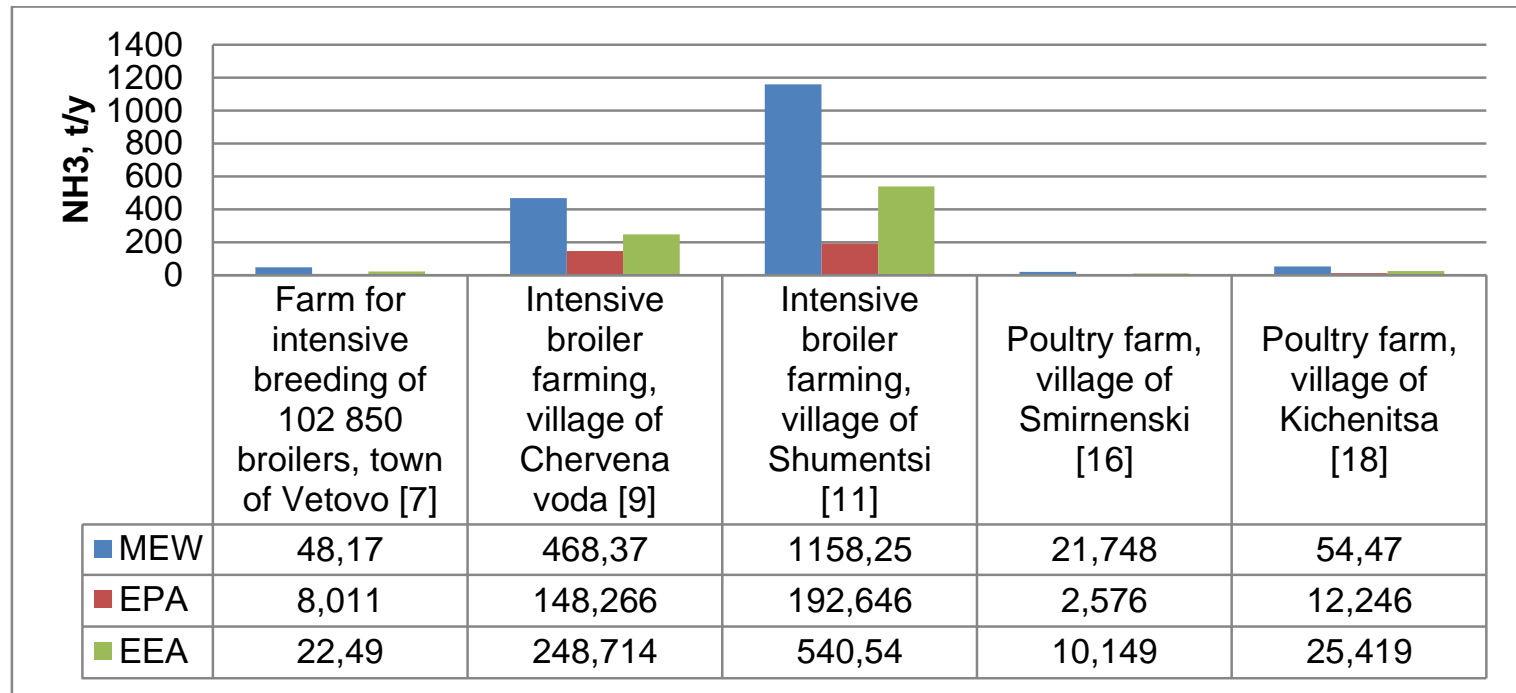

Chart 3.3.-1 Inventory results for ammonia pollutant from vital activity of birds in the perused sites.

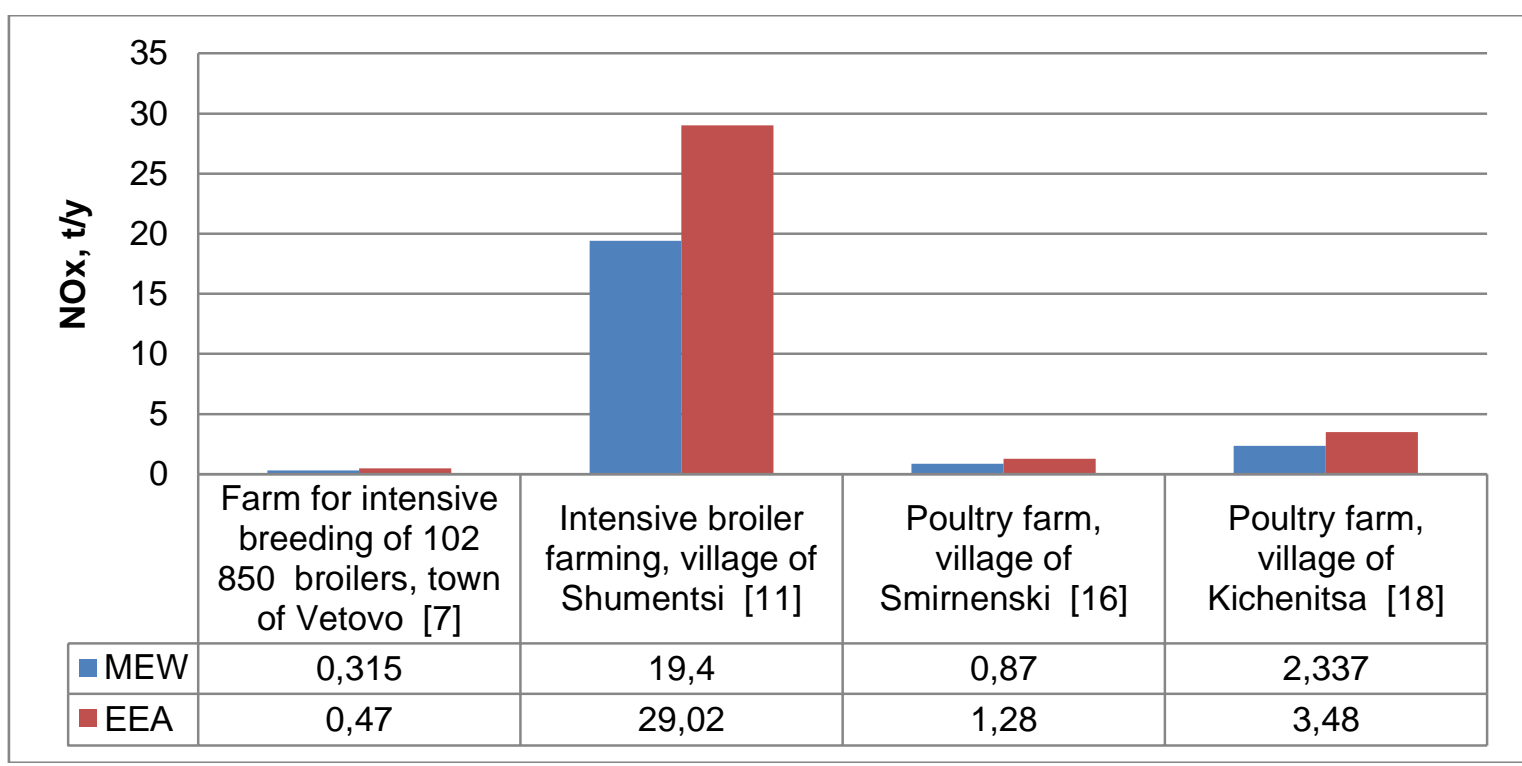

Chart 3.3.-2 Inventory results for nitrogen oxides pollutant from heating of production premises in the perused sites.

d. Potential consequences of applying different inventory methods on pollutants in similar sites

Registered deviations in the inventory results of the reviewed pollutants reach up to 6 times increase in the annual emission compared to the lowest calculated value for the ammonia pollutant from industrial buildings. These results create a possibility for unequal assessment for similar sites of different investors, depending on the methodology chosen by the independent expert involved in the assessment of Ambient air component in the EIA report.

Using an Updated uniform inventory methodology for emissions of harmful substances in the air, approved by MEW, shows the highest values of ammonia pollutant from production buildings. Despite the explicit description by the authors of the methodology that the emission factor for the pollutant covers ammonia emissions from excrement in all activities involved in animal husbandry - livestock care, manure storage, spreading - in some of the perused EIA reports this emission factor is used for calculation of emissions only from vital activity of birds. This leads to 
considerable deviations in the inventory results for these sites, compared to results obtained by using the other two methods discussed.

\section{Conclusions}

The conducted study is limited in territorial and temporal scope. It covers sites for the 2013-2016 period, approved for implementation on the territory of RIEW Ruse - Ruse, Razgrad and Silistra districts.

Despite the limitations, a significant difference has been established between net annual emissions of reviewed pollutants in each of the applied inventory methods.

A thorough study of the approved environmental impact assessment reports is necessary on national level, covering a larger number of sectors in the survey. Based on the detailed research, using the most appropriate methodology for each sector should be prioritized.

For the purposes of the environmental impact assessment reports, a uniform assessment methodology should be created, including the following:

- Applicable inventory methodology for the basic activities in each sector;

- Quantity and quality assessment of the result obtained from annual inventory of pollutants, identified during research;

- Instructions on applicability in new and existing sites, subject to expansion;

Drawing up a uniform methodology will ensure equal assessment of similar sites.

\section{Acknowledgements}

Thanks to the employees of Regional Inspectorate of Environment and Water - Ruse for providing comprehensive information on procedures performed in compliance with Chapter Six of the Law on Environmental Protection.

I'm grateful to my principal scientists Asst Professor, Dr. sc M. Philipova and Asst Professor, Dr. sc Ivanka Zheleva for the assistance provided in writing of this article.

\section{References}

1. Updated uniform inventory methodology for emissions of harmful substances in the air (Order № 165/20.02.2013 of MEW), - http://eea.government.bg/bg/legislation/air/methodology

2. EMEP/EEA Air pollutant emission inventory guidebook of EEA, 2009 http://www.eea.europa.eu/publications/emep-eea-emission-inventory-guidebook-2009

3. EMEP/EEA Air pollutant emission inventory guidebook of EEA, 2013 http://www.eea.europa.eu/publications/emep-eea-guidebook-2013

4. AP-42, Compilation of Air Pollutant Emission Factors of EPA - U.S. Environmental Protection Agency - https://www3.epa.gov/ttnchie1/ap42/

5. Environmental Protection Act (publ. SG issue 25/09/2002; last amended SG issue 101 22/122015) - http://www.lex.bg/bg/laws/ldoc/2135458102

6. Public registers for EIA procedures - http://registers.moew.government.bg/ovos/

7. EIA Report for project "Farm for intensive breeding of 102850 broilers with location ZLP III, ZLP IV, ZLP V, ZLP X and ZLP XI, quarter 180 according to the town plan of Vetovo, Ruse district", concluded by Decision № RM 1-1/2013

8. EIA Report for project "Developing and expanding by an surface method of project "Esennitsite VIII section" for extraction of quartz - kaolin raw material on the territory of the town of Vetovo, Ruse district", concluded by Decision № RM 2-2/2013

9. EIA Report for project "Expanding the capacity of a facility for intensive breeding of poultry (growing up parents for broilers and parent stocks for broilers) from 625174 to 1058010 bird capacity, with location properties № 000175 and № 000227 on the territory of the village of 
Chervena voda, Ruse municipality, concluded by Decision № RM 3-4/2013 http://registers.moew.government.bg/ovos/lot/149

10. EIA Report for project "Construction of port Toepfer-Silistra, with location LP identification 00895.506.78 according to the cadastral map of the village of Aidemir, Silistra municipality", concluded by Decision № RM 1-1/2014 - http://registers.moew.government.bg/ovos/lot/3866

11.EIA Report for project "Repairs, expansion and equipment of a facility for broiler farming and reaching of 314570 general bird capacity with location: property number 050036 on the territory of the village of Shumentsi, Tutrakan municipality", concluded by Decision № RM 2$\underline{2 / 2014}$

12. EIA Report for project "Construction of installation for hazardous waste incineration for "Biovet" AD - branch Razgrad and production of thermal energy, with location: LP identification 61710.503.6334 in East industrial area of the town of Razgrad", concluded by Decision № RM 33/2014 - http://registers.moew.government.bg/ovos/lot/2291

13. EIA Report for project "Extraction of subsurface natural resources - construction materials (limestone) from "Pravda" area on the territory of the village of Pravda, Dulovo municipality, Silistra region", concluded by Decision № RM 1-1/2015 http://registers.moew.government.bg/ovos/lot/8019

14. EIA Report for project "Increasing the capacity of an existing installation for tar and bitumen production from 10000 t/y to 200000 t/y by raw material deposited in ZLP XX and ZLP XXVI according to the plan of "TM" AD - Ruse, and construction of a new complex "Hydrocracking" within ZLP XII according to the plan of "TM" AD - Ruse for production of petrol and diesel fuels from heavy petroleum fractions with a capacity of 250000 t/y by raw material", concluded by Decision № RM 2-2/2015 for partial approval of the investment http://registers.moew.government.bg/ovos/lot/2009

15. ElA Report for project "Merging of two existing stock breeding facilities into one, reconstruction of existing and construction of new buildings in order to increase the capacity of the livestock breeding facility - pig farm located on the territory of the village of Popina, Silistra municipality", concluded by Decision № RM 3-3/2015

16. EIA Report for project "Construction of poultry farm for broiler breeding with a capacity of 54000 broilers, with location: property № 005077 on the territory of the village of Smirnenski, Vetovo municipality", concluded by Decision № RM 4-4/2015

17. EIA Report for project "Merging of five existing livestock breeding facilities (piggeries) into one and increasing the capacity of the farm, with location properties 056001, 053002, 053003, $053004,053005,053006,053007$ on the territory of the village of Vetren, Silistra municipality", concluded by Decision № RM 5-7/2015

18. EIA Report for project "Increasing the capacity of an existing poultry breeding building, repair, reconstruction and entry into service of two existing poultry breeding buildings with the purpose of reaching joint capacity of 122724 spaces for birds, property № 000058 on the territory of the village of Kichenitsa, Razgrad municipality, concluded by Decision № RM 1$\underline{1 / 2016}$ - http://registers.moew.government.bg/ovos/lot/10784 